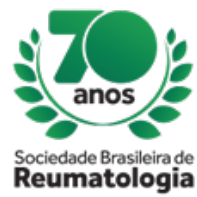

\title{
ARTICULAR SONOGRAPHIC FINDINGS IN PATIENTS WITH PSORIASIS
}

BARBARA CARVALHO KLEMZ (UNIVERSIDADE FEDERAL DE SÃO PAULO, SÃO PAULO, SP, Brasil), KARINE RODRIGUES LUZ (UNIVERSIDADE FEDERAL DE SÃO PAULO, SÃO PAULO, SP, Brasil), ADRIANA MARIA PORRO (UNIVERSIDADE FEDERAL DE SÃO PAULO, SÃO PAULO, SP, Brasil), POLIANNA OLIVEIRA MATOS SOARES (MED NOBILLI CLINIC, SÃO PAULO, SP, Brasil), MARCELO MEDEIROS PINHEIRO (UNIVERSIDADE FEDERAL DE SÃO PAULO, SÃO PAULO, SP, Brasil)

\section{BACKGROUND}

Articular ultrasound (US) has been increasingly used to detect subclinical involvement in several chronic inflammatory arthropathies, especially in initial cases and diagnostic doubts. However, there are still many gaps for the better characterization and definition of synovitis, entesopathy in patients with psoriasis (Ps) and psoriatic arthritis.

Objectives: To describe the ultrasound findings in joints, entheses, tendons and nails of patients with psoriasis, asymptomatic from the articular point of view.

\section{MATERIALS AND METHODS}

A total of 56 patients with psoriasis (Ps) and 30 healthy controls $(\mathrm{HC})$ were included in this case-control study. Patients with previous diagnosis of any rheumatic disease were excluded. The following clinical instruments were applied in all research subjects: PASI, PEST, nail dystrophy, number of painful and swollen joints, count of enthesis, dactylitis and axial complaints. In addition, they performed US in 1232 joints, 672 enthesis and 1792 tendons, as well as the GUESS score (Glasgow Ultrasound Enthesitis Scoring System). The assessments were made by dermatologist and rheumatologists, blinded to all assessments. Patients with Ps were separated into 2 groups, with and without clinical nail dystrophy. P lower than 0.05 was considered significant.

\section{RESULTS}

Most patients with Ps were caucasian, male, with mean age of $49 \pm 10.7$ years, mean disease time of 15 \pm 9.7 years and PASI $6,85 \pm 8$.9. The US detected subclinical synovitis in $41.1 \%$ of psoriasis patients and more enthesitis in the lower limbs of patients with Ps than in $\mathrm{HC}$ ( $39.6 \%$ and $9.3 \%$, respectively, $p<0.001)$. In 222 of the 560 enthesis (39.6\%) of the lower limbs, the gray-scale US detected at least 1 indicative sign of entesithis, especially in the achilles tendon (106/560; 18.9\%) versus HC (28 of 300 entheses or $9.3 \%$, and 13 of 300 or $4.3 \%$, respectively). GUESS score was significantly higher in patients with Ps than HC $(p<0.0001)$. Patients with Ps had a greater thickness in all tendons evaluated when compared to the HC $(p<0.008)$. The paratendinitis of the extensor I of the toes was more frequent in patients with Ps than in the $\mathrm{HC}(\mathrm{p}<0.03)$.

\section{CONCLUSION}

Subclinical articular involvement is more frequent in patients with Ps than $\mathrm{HC}$, suggesting a preclinical involvement. US seems to be an important tool for initial cases and doubts, especially when there is involvement of the lower limbs, and confirms the usefulness of the GUESS score in clinical practice. The higher frequency of paratendinitis of the extensor I of the toes was the unpublished finding of this study. 